\title{
OPERATIONAL PARAMETERS OF SOYBEAN SEEDING IN SANTA FE SYSTEM
}

\author{
CARlos A. CHIODEROLI ${ }^{1}$, CARLOS E. A. FURLANI ${ }^{2}$, AISLAN O. AGUIAR ${ }^{3}$, \\ FÁBIO A. CAVICHIOLI ${ }^{4}$, MARCELO T. CASSIA ${ }^{4}$
}

\begin{abstract}
The use of no tillage system associated with the crop-livestock integration is an alternate managing that promotes the accumulation of dry matter in the soil, an essential fact to make the system sustainable and profitable. The aim of this study was to evaluate the operational performance of a planter-tractor set on maize straws intercropped with Urochloa, in different seeding modes. The soybean crop was seed on the intercropping of two forage species (Urochloa brizantha and Urochloa ruziziensis) in five cropping systems: MBL (Maize with Urochloa in the maize seeding row, mixed with base fertilizer and deposited at $0.10 \mathrm{~m}$ ), MBE (Maize with Urochloa seeded between rows at the same day of seeding maize), MBC (Urochloa between rows of maize seeded with the covering fertilizer at the $\mathrm{V}_{4}$ stage), MBLA (Maize with Urochloa by broadcast seeding at the $\mathrm{V}_{4}$ stage ) and MS (Single Maize: control). The following variables were evaluated: dry mass of maize straw, dry mass of forages and total dry mass of straw; and for the operational parameters the speed of seeding, wheel slippage, traction force and average power at the drawbar. The results showed that the amount of straw produced by maize intercropping with Urochloa, interferes in the operational performance of the tractor-planter at the operation of soybean seeding, i.e., areas with higher amount of straw promote greater energy demand, as well as higher wheel slippage.
\end{abstract}

KEYWORDS: no tillage system, crop-livestock integration, slip, operating performance.

\section{PARÂMETROS OPERACIONAIS DE SEMEADURA DE SOJA EM SISTEMA SANTA FÉ}

RESUMO: O uso do plantio direto, associado ao sistema de integração lavoura-pecuária, é uma alternativa de manejo que promove o acúmulo de massa seca no solo, fato imprescindível para tornar o sistema sustentável e lucrativo. O trabalho teve por objetivo avaliar o desempenho operacional do conjunto trator-semeadora sobre palhadas de milho consorciado com urochloas, em diferentes modalidades de semeadura. A cultura da soja foi semeada sobre o consórcio de duas espécies forrageiras (Urochloa brizantha e Urochloa ruzizienses), em cinco sistemas de cultivo: milho com Urochloa na linha de semeadura do milho, misturados ao adubo de base e depositados a 0,10 m (MBL); milho com Urochloa semeados na entrelinha, no mesmo dia da semeadura do milho (MBE); Urochloa na entrelinha do milho semeada junto ao adubo de cobertura no estádio $\mathrm{V}_{4}$ (MBC); milho com Urochloa semeados a lanço no estádio $\mathrm{V}_{4}$ (MBLA) e milho solteiro (Testemunha). Foram avaliadas as variáveis: massa seca da palha do milho, massa seca das forrageiras e massa seca total de palha; e para os parâmetros operacionais: a velocidade de semeadura, patinagem dos rodados, força de tração e potência média na barra de tração. A quantidade de palha produzida pelo consórcio de milho com urochloas interfere no desempenho operacional do conjunto trator-semeadora na operação de semeadura da soja, ou seja, áreas com maior quantidade de palha promoveram maior demanda energética, assim como maior patinagem dos rodados.

PALAVRAS-CHAVE: sistema plantio direto, integração lavoura-pecuária, patinagem, desempenho operacional.

\footnotetext{
${ }^{1}$ Eng ${ }^{\mathrm{o}}$ Agrônomo, Doutorando do Programa de Pós-Graduação em Ciência do Solo, Faculdade de Ciências Agrárias e Veterinárias UNESP, Departamento de Engenharia Rural (LAMMA), Jaboticabal - SP, ca.chioderoli@ uol.com.br.

${ }^{2}$ Eng ${ }^{\mathrm{o}}$ Agrônomo, Professor Adjunto, Departamento de Engenharia Rural, Faculdade de Ciências Agrárias e Veterinárias - UNESP, Jaboticabal - SP.

${ }^{3}$ Eng $^{\mathrm{o}}$ Agrônomo, Departamento de Engenharia Rural (LAMMA), Jaboticabal - SP.

${ }^{4}$ Pós-graduandos, Departamento de Engenharia Rural (LAMMA), Faculdade de Ciências Agrárias e Veterinárias - UNESP, Jaboticabal - SP.
}

Recebido pelo Conselho Editorial em: 28-6-2011

Aprovado pelo Conselho Editorial em: 12-5-2012 


\section{INTRODUCTION}

The practice of intercropping the crops that produces grains with tropical forages in summer crop is being used by technicians and agriculturists in order to anticipate the forage establishment, particularly in regions where winter is dry and does not allow proper development of the off-season crops. This method allows the use of forages to the straw production and to the installation of pasture (CHIODEROLI et al., 2010).

In the system of crop-livestock integration, the production of grain crops, especially maize, sorghum and rice, intercropped with tropical forages, especially those of the genus Urochloa, is known as the Santa Fe system, in which the forage can have a dual purpose: serving for the farm, from late summer to early spring, and later to the formation of straw to maintenance of no tillage system - NTS (CUNHA et al., 2007).

The NTS and the integrated crop-livestock management are alternatives that reconcile the maintenance and even the increase of productivity with greater rationality of inputs used (SANTOS et al., 2008). In the tropical region of Brazil, with high temperatures and well-defined seasons, that is dry in winter and high precipitation in summer, decomposition and mineralization of organic matter are very fast, however, in subtropical climates this behavior is reversed.

So, to keep the annual straw supply required by NTS in tropical regions is of fundamental importance the establishment of crops with high straw production with an adequate amount to cover the ground, and which minimizes the accelerated decomposition process. The choice of plant species, as to its dry matter production and decomposition time are key features because they interfere directly in the amount of straw on the soil and consequently in soil chemical properties, including the CTC, which directly affect the dynamics of cations (ANDREOTTI et al., 2008). Perennial forage species as Urochloa decumbens, $U$. brizantha-Panicum maximum cv. Tanzania and P. maximum cv. Mombasa, besides provide lots of dry mass, which is essential for the NTS, have high carbon / nitrogen ratio $(\mathrm{C} / \mathrm{N})$, slowing the rate of straw decomposition, increasing the possibility of use in warmer regions to protect the soil against erosion and solar radiation for longer time (TIMOSSI et al., 2007). Thus, the species of genus Urochloa, in general, have been considered prominent options in the formation of straw to the NTS, due to good dry mass production and high $\mathrm{C} / \mathrm{N}$ ratio in its composition, slowing the decomposition (NUNES et al., 2006).

Thus, the Santa Fe system has been studied by several researchers, who reported that in most studies, the presence of forage did not affect grain productivity of maize (FREITAS et al., 2005; JAKELAITIS et al., 2005; JAKELAITIS et al., 2006). Therefore, the intercropping, when practiced technically correct, provides the increase of amount of straw, seeking better soil cover to the success of direct seeding and often increasing the subsequent crop productivity, or the anticipation of the pasture formation.

The determination of operating and energy parameters of the machines of the straw from the intercropping proceeding from Santa Fe system, is of great importance, because the straw cut, efficiency in the distribution of seeds and fertilizers as well as grain productivity, is dependent on different amounts of straw mass produced, as well as the morphological characteristics of each forage.

These parameters can usually be assessed by the average demand of power traction, power bar and wheel slippage. The parameter power bar is the function of the bar strength on the drawbar and the operating speed (SALVADOR et al., 2009).

Accordingly, the aim of this study was to evaluate the operating performance of the plantertractor on maize straws intercropped with Urochloas in different seeding modes and identify the effect caused by the straw at the time of seeding the soybean. 


\section{MATERIAL AND METHODS}

The experiment was conducted in the crop year 2010/2011 in the experimental area of Laboratory of Machinery and Agricultural Mechanization of UNESP/Jaboticabal - state of São Paulo (SP), Brazil, located in the geodetic coordinates: latitude $21^{\circ} 14^{\prime} \mathrm{S}$ and longitude $48^{\circ} 16^{\prime} \mathrm{W}$, with an average altitude of $560 \mathrm{~m}$, average slope of $4 \%$ and Cwa climate (subtropical), according to Köeppen classification. The water supply was carried out by the system of sprinkler irrigation to meet the minimum needs of the crops.

The experimental area is classified as Typic Eutroferric Red Latossol according to the Brazilian System of Soil Classification (EMBRAPA, 2006), containing 51\% of clay, 20\% of sand and $29 \%$ silt, and at the time of sowing the soybean the soil had a water content of $0.32 \mathrm{~kg} \mathrm{~kg}^{-1}$ and $0.30 \mathrm{~kg} \mathrm{~kg}^{-1}$, with soil mechanical resistance to penetration (SMRP) of $0.87 \mathrm{MPa}$ and $1.82 \mathrm{MPa}$ for the layers of $0,0-0.10 \mathrm{~m}$ and $0.11-0.20 \mathrm{~m}$, respectively.

The treatments were consisted by two species of urochloas (Urochloa brizantha and Urochloa ruzizienses) in four modes of intercropping of urochloas with maize and control treatment. The treatments were: Maize with Urochloa in the row, with Urochloa mixed with the maize base fertilizer and deposited at $0.10 \mathrm{~m}$ on the side of the maize seed (MBL); Maize Urochloa between rows, planted between rows in the same day of sowing of the maize, with the presence of an intermediate line sowing (MBE); Maize Urochloa between rows sown at the time of the covering fertilization of the maize at the $\mathrm{V}_{4}$ stage (MBC); Maize Urochloa broadcast seeded at the time of covering fertilization (MBLA); Single Maize (CONTROL).

The experimental portion was $180 \mathrm{~m}^{2}$, consisting of eight maize rows, with $0.90 \mathrm{~m}$ of space and with $25 \mathrm{~m}$ long, with $15 \mathrm{~m}$ of carriers to maneuver machinery and implements, and carriers of $1 \mathrm{~m}$ for separation of experimental blocks. The useful area evaluated to determine the dry mass of maize straw and forage were the two central lines, each one with $5 \mathrm{~m}$.

In the summer harvest, the soybean crop was sown on the straw of previous treatments (intercropping of maize and Urochloa) with nine combinations. The data were treated in the experimental delineation of randomized blocks with nine treatments in a factorial scheme $2 \times 4+1$, with four repetitions: two urochloas (Urochloa brizantha and Urochloa ruzizienses) and four intercropping systems, and a control.

In pulverization operations, the sowing of forages between rows and covering fertilization of the maize, we used a Ford 6600 tractor, 4x2, with maximum engine power of $66.2 \mathrm{~kW}$ (90 hp), a PJ-600 pulverizer equipped with 24 110-02 tips, spaced with $0.5 \mathrm{~m}$ and covering fertilizer configured with 4 doubled disks (13" x 15") and two tanks with a capacity of 220 liters. To perform the seeding of the soybean we used the Valtra BM-125i, 4x2 TDA tractor, with engine maximum power of $91.9 \mathrm{~kW}(125 \mathrm{hp})$, rotation of 2,300 rpm and working in the L2 march. It had a mass of $7,000 \mathrm{~kg}$ (40\% forward and 60\% rear), 14,9-24 R1 front tires with inflation pressure of 18 psi (124 kPa), 18.4-34 R1 rear tires with inflation pressure of $22 \mathrm{psi}(152 \mathrm{kPa})$ and drawbar height of $0.415 \mathrm{~m}$.

The precision seeder-fertilizer used had seven lines spaced with $0.45 \mathrm{~m}$, configured to direct no tillage system with cutting disk to straw of 18", shank acting on the depth of $0.14 \mathrm{~m}$, with $0.027 \mathrm{~m}$ tip thickness, $0.01 \mathrm{~m}$ of stem thickness, distance from the cutting disk to the stem of $0.12 \mathrm{~m}$ and angle of attack of $20^{\circ}$, mismatched double disk $15^{\prime \prime}$ for opening furrow for deposition of the seed, pneumatic distributor for seeds, controlling wheel of parallel depth and compactor wheels in "V". The weight of the seeder was 2,070 kg with fertilizer tank capacity for $1,310 \mathrm{~kg}$ and $200 \mathrm{~kg}$ for seed, and in the operation the fertilizer tank was stocked with $655 \mathrm{~kg}$ (half load).

Soybean was sown in $12 / 08 / 2010$ with a space between rows of $0.45 \mathrm{~m}$, with cultivar BRS Valiosa RR, with 16 seeds per meter. For the treatment of seeds were used $100 \mathrm{~g}$ of Carboxin (i.a), $50 \mathrm{~g}$ of Fipronil (i.a) per $100 \mathrm{~kg}$ of seed, and $60 \mathrm{~mL}$ of Nitragin inoculant liquid $\left(1.10^{9} \mathrm{cells} \mathrm{g}^{-1}\right)$. It was used the mineral fertilization of $300 \mathrm{~kg} \mathrm{ha}^{-1}$ of commercial formula (04-20-20) at sowing. 
On 12/22/2010 was made an application of $720 \mathrm{~g} \mathrm{ha}^{-1}$ of Glyphosate in total area for removal of remaining weeds and the application of the insecticide Methamidophos at a dose of $600 \mathrm{~g} \mathrm{ha}^{-1}$ (i.a) to the caterpillar control (Anticarsia gemmatalis). On 02/03/2011, for the control of soybean rust, was applied $60 \mathrm{~g} \mathrm{ha}^{-1}$ of picoxystrobin (i.a) $+24 \mathrm{~g} \mathrm{ha}^{-1}$ cyproconazole (i.a). A second and third application with the same dosage was made in the days 02/28/2011 and 03/23/2011. Some applications for bug control (Euchistus heros and Nezara viridula) were performed in this time interval using $55 \mathrm{~g}$ of cypermethrin (i.a) $+27.5 \mathrm{~g}$ of thiamethoxam (i.a).

The determination of the mass of maize straw was obtained by weighing all plants of the portion useful area, with a discount, after the track, of the weight of the grains, resulting in a green mass of the straw. A sample was taken and submitted to drying in a greenhouse with forced air circulation for $72 \mathrm{~h}$ at $65{ }^{\circ} \mathrm{C}$ determining the water content and subsequently was calculate the dry mass of straw per hectare. For the dry matter of forages was used an iron frame with area of $0.25 \mathrm{~m}^{2}$, collecting four sub-samples per portion on treatments, with the forage between the rows and broadcast, and for the forage sown on the line, collected up to $2 \mathrm{~m}$ of two lines of the portion useful area. The material was weighed and a sample was taken to the greenhouse with forced air circulation for $72 \mathrm{~h}$ at $65^{\circ} \mathrm{C}$, determining the dry mass for the calculation of dry matter production, emphasizing that the total dry mass of straw was obtained by the sum of the maize straw and the forage, which represented the initial condition for seeding.

The obtaining of the data of displacement speed, wheel slippage and the average of the strength bar was performed using a data acquisition system model "micrologger CR23X, Campbell Scientific". Displacement speed values were obtained by the radar unit located on the right side of the tractor, forming an angle of $45^{\circ}$ with the ground, RVS type II, with a precision of $0.1 \mathrm{~km} \mathrm{~h}^{-1}$. The wheel slippage was obtained by inductive sensors S\&E I, model GIDP-60-U-12V, which performed the conversion of rotary motion into electrical pulses, generating 60 pulses per wheel slippage of the tractor. For the calculation of wheel slippage the following formula was used:

$$
\mathrm{P}=\left(1-\frac{\mathrm{NPC}}{\mathrm{NPS}}\right) 100
$$

in which,

P - wheel slippage, \%;

NPC - number of sensor pulses, tractor operating with load on the drawbar, and

NPS - number of sensor pulses, tractor operating without load on the drawbar.

By means of a load cell connected to a data acquisition system, was obtained the average strength traction thereby finding the value of the drawbar power (eq.(2)):

$\mathrm{PB}=\mathrm{Fm} \mathrm{v}$

in which,

$\mathrm{PB}$ - power on the drawbar, $\mathrm{kW}$;

$\mathrm{F}_{\mathrm{m}}$ - strength of traction on the bar, $\mathrm{kN}$, and

$\mathrm{v}$ - displacement real speed, $\mathrm{m} \mathrm{s}^{-1}$.

The data were submitted to a variance analysis and, when the value of the $\mathrm{F}$ test was significant $(\mathrm{p}<0.1)$, was held the comparison of averages by Tukey test at $10 \%$ of probability.

\section{RESULTS AND DISCUSSION}

The assessment of the productivity of dry straw obtained by intercropping maize with the forage was essential in order to interpret the results of operational performance on these straws, since the total dry mass of straw is the most important variable to be analyzed, because represents the initial condition for soybean planting. According to Table 1, to the variable dry mass of maize 
straw, there was no significant difference in the evaluated treatments, i.e., the forage and seeding modes did not affect this variable, which demonstrates the high adaptability of maize in the Santa Fe system.

TABLE 1. Mean values for dry mass of maize straw, dry mass of Urochloa and total dry mass of straw in the system of maize intercropping with Urochloa in different methods of seeding.

\begin{tabular}{|c|c|c|c|c|}
\hline \multirow{2}{*}{\multicolumn{2}{|c|}{ Variation Elements }} & \multicolumn{3}{|c|}{ Evaluated Parameters } \\
\hline & & \multirow{2}{*}{$\begin{array}{c}\text { Dry Mass of } \\
\text { Maize Straw } \\
\left(\mathrm{kg} \mathrm{ha}^{-1}\right)\end{array}$} & \multirow{2}{*}{$\begin{array}{c}\begin{array}{r}\text { Urochloa } \\
\text { Dry Mass } \\
\left(\mathrm{kg} \mathrm{ha}^{-1}\right)\end{array} \\
3.768 \mathrm{~b}\end{array}$} & \multirow{2}{*}{$\begin{array}{c}\begin{array}{c}\text { Total Dry } \\
\text { Mass of Straw } \\
\left(\mathrm{kg} \mathrm{ha}^{-1}\right)\end{array} \\
12.306\end{array}$} \\
\hline \multirow[b]{2}{*}{ Forages $(\mathrm{F})$} & $U$. brizantha & & & \\
\hline & U. ruzizienses & 7.350 & $4.778 \mathrm{a}$ & 12.128 \\
\hline \multirow{5}{*}{$\begin{array}{l}\text { Seeding } \\
\text { Modes } \\
(\mathrm{M})\end{array}$} & MBL & 7.221 & $2.991 \mathrm{~b}$ & 10.212 \\
\hline & $\mathrm{MBE}$ & 6.980 & $5.950 \mathrm{a}$ & 12.930 \\
\hline & $\mathrm{MBC}$ & 10.289 & $5.899 \mathrm{a}$ & 16.188 \\
\hline & MBLA & 7.752 & $4.135 \mathrm{ab}$ & 11.887 \\
\hline & Control & 7.607 & $0 \mathrm{c}$ & 7.607 \\
\hline \multirow{3}{*}{ F Value } & $\mathrm{F}$ & $1.319^{\mathrm{NS}}$ & $4.702 *$ & $0.024^{\mathrm{NS}}$ \\
\hline & M & $1.476^{\mathrm{NS}}$ & $16.864 *$ & $5.211^{*}$ \\
\hline & $\mathrm{F}^{*} \mathrm{M}$ & $1.975^{\mathrm{NS}}$ & $1.211^{\mathrm{NS}}$ & $2.341 *$ \\
\hline \multirow{2}{*}{ DMS } & $\mathrm{F}$ & 1.770 & 796 & 1.980 \\
\hline & M & 4.412 & 1.984 & 4.935 \\
\hline C.V. (\%) & & 38.51 & 32.91 & 28.23 \\
\hline
\end{tabular}

Averages followed by the same letters do not differ between each other by the Tukey test to a level of 10\% of probability. MBL: Maize intercropped with Urochloa on the row; MBE: Maize intercropped with Urochloa between the rows; MBC: Maize intercropped with Urochloa covered on stage $\mathrm{V}_{4}$; MBLA: Maize intercropped with Urochloa broadcasted in $\mathrm{V}_{4}$; and MS: Control. NS: without significance; C.V.: coeficient of variation (\%).

For the mass values of forages, there was a significant difference for both treatments, the Urochloa ruzizienses showed higher values compared to Urochloa brizantha, showing the efficiency of this forage in the production of straw, which can be explained by the cespitose and creeping growth, and to the better use and occupation of the root system in the soil profile. The results of MACHADO et al. (2010) corroborate this research because they concluded that the forage Uruchloa ruziziensis and Uruchloa decumbens, due to staying on growth throughout the dry season and the ease of desiccation, may be better utilized for the purpose of covering the soil.

For the treatment seeding mode, the largest production of forage mass of straw occurred in the treatment of MBE and MBC, differing significantly from the other treatments $(\mathrm{p}<0.1)$, except for the MBLA, which showed similar results. Most forage production of MBE and MBC occurs due to less competition provided by the maize when compared to other treatments, allowing fast initial development of forage and higher photosynthetic efficiency, becoming the fastest growing end, i.e., accumulation of dry mass. The data from this study agree with JAKELAITIS et al. (2005) who observed that seeding systems of $U$. brizantha single or in lines and broadcast intercropped with maize, strongly influenced forage production.

For the values of total dry mass of straw, it appears that there was significant interaction between forage and seeding mode, and the unfolding of mode within the forage are on Table 2.

Based on the figures, we can say that for the MBL, the $U$. brizantha had higher values of dry matter compared with the $U$. ruzizienses, demonstrating the high competitiveness of forage intercropped with maize, due to erect and large growth, and the lower water and nutrients requirement. For the unfolding of $U$. brizantha in the seeding modes, it appears that the greatest 
amount of dry matter occurred in the treatment of $\mathrm{MBC}$, differing significantly from the control, but being equal to the other treatments.

TABLE 2. Mean values obtained of the development for total dry mass of straw, within forages for different methods of seeding.

\begin{tabular}{cclc}
\hline \multirow{2}{*}{ Variation Elements } & \multicolumn{2}{c}{ Forages (F) } \\
\cline { 2 - 4 } & MBL & $12.702 \mathrm{Aab}$ & B.Ruzizienses \\
\hline \multirow{2}{*}{ Seeding } & MBE & $11.314 \mathrm{ab}$ & $7.721 \mathrm{Bb}$ \\
Modes & MBC & $17.083 \mathrm{a}$ & $14.545 \mathrm{a}$ \\
$(\mathrm{M})$ & MBLA & $12.826 \mathrm{ab}$ & $15.294 \mathrm{a}$ \\
& Control & $7.607 \mathrm{~b}$ & $10.950 \mathrm{ab}$ \\
& F & 4.175 & $7.607 \mathrm{~b}$ \\
\hline \multirow{2}{*}{ DMS } & M & 6.371 & \\
\end{tabular}

Averages followed by different small letters column and capital letters in the lines defer between each other by the Tukey test to a level of $10 \%$ of probability. MBL: Maize intercropped with Urochloa on the row; MBE: Maize intercropped with Urochloa between the rows; MBC: Maize intercropped with Urochloa covered on stage $\mathrm{V}_{4}$; MBLA: Maize intercropped with Urochloa broadcasted in $\mathrm{V}_{4}$; and MS: Control.

Similar results occurred for $U$. ruzizienses in the seeding modes, with higher values for MBE and MBC, differing from MBL $(\mathrm{p}<0.1)$ and the control, but equal to the mode MBLA. Overall, we conclude that seeking greater amount of straw on the soil surface, the MBC is the most recommended treatment, but the control had the lowest values. With these results it is possible to verify the initial condition for soybean planting, serving as explanatory variables in the behavior of operating and energy parameters.

For operating parameters, the results showed that the operation of planting soybeans on maize straws and forage, gave significant effect to the front wheels slippage, average strength of traction and average power bar (Table 3 ).

TABLE 3. Mean values obtained for speed of seeding, slip of front wheels and rear wheels, traction average force and average power in the drawbar in soybean seeding operation on maize straw intercropped with Urochloa.

\begin{tabular}{|c|c|c|c|c|c|c|}
\hline \multirow{2}{*}{\multicolumn{2}{|c|}{ Elements of Variation }} & \multirow{2}{*}{$\begin{array}{c}\text { Speed } \\
\left(\mathrm{km} \mathrm{h}^{-1}\right)\end{array}$} & \multicolumn{2}{|c|}{ Wheel Slippage (\%) } & \multirow{2}{*}{$\begin{array}{c}\text { Average TF } \\
(\mathrm{kN})\end{array}$} & \multirow{2}{*}{$\begin{array}{c}\begin{array}{c}\text { Average PD } \\
(\mathrm{kW})\end{array} \\
\end{array}$} \\
\hline & & & FW & RW & & \\
\hline \multirow{2}{*}{$\begin{array}{c}\text { Forages } \\
\text { (F) }\end{array}$} & U. brizantha & 3.5 & 14.9 & 22.5 & 23.3 & 22.7 \\
\hline & U. ruzizienses & 3.6 & 16.4 & 20.7 & 22.4 & 22.4 \\
\hline \multirow{5}{*}{$\begin{array}{l}\text { Seeding } \\
\text { Modes } \\
\text { (M) }\end{array}$} & $\mathrm{MBL}$ & 3.7 & $15.1 \mathrm{ab}$ & 21.6 & $20.3 \mathrm{~b}$ & $20.1 \mathrm{~b}$ \\
\hline & MBE & 3.5 & $15.7 \mathrm{ab}$ & 19.0 & $23.4 \mathrm{ab}$ & $23.0 \mathrm{ab}$ \\
\hline & $\mathrm{MBC}$ & 3.5 & $20.3 \mathrm{a}$ & 24.2 & $26.0 \mathrm{a}$ & $25.3 \mathrm{a}$ \\
\hline & MBLA & 3.4 & $14.2 \mathrm{ab}$ & 20.9 & $23.0 \mathrm{ab}$ & $22.0 \mathrm{ab}$ \\
\hline & Control & 3.5 & $9.4 \mathrm{~b}$ & 23.8 & $20.7 \mathrm{~b}$ & $20.3 \mathrm{~b}$ \\
\hline \multirow{3}{*}{ F Value } & $\mathrm{F}$ & $0.13^{\mathrm{NS}}$ & $0.70^{\mathrm{NS}}$ & $0.86^{\mathrm{NS}}$ & $0.62^{\mathrm{NS}}$ & $0.68^{\mathrm{NS}}$ \\
\hline & M & $0.57^{\mathrm{NS}}$ & $3.09 *$ & $0.97^{\mathrm{NS}}$ & $3.13 *$ & $2.81 *$ \\
\hline & $\mathrm{F}^{*} \mathrm{M}$ & $1.39^{\mathrm{NS}}$ & $0.55^{\mathrm{NS}}$ & $0.13^{\mathrm{NS}}$ & $0.78^{\mathrm{NS}}$ & $0.89^{\mathrm{NS}}$ \\
\hline \multirow{2}{*}{ DMS } & $\mathrm{F}$ & 0.29 & 3.05 & 3.34 & 2.00 & 1.94 \\
\hline & M & 0.30 & 7.61 & 8.34 & 5.00 & 4.85 \\
\hline C.V. (\%) & & 14.50 & 34.21 & 26.89 & 15.29 & 15.17 \\
\hline
\end{tabular}

Averages folowed without letters or by equal letters Do not difer between each other by the Tukey test to a level of $10 \%$ of probability. MBL: Maize intercropped with Urochloa on the row; MBE: Maize intercropped with Urochloa between the rows; MBC: Maize intercropped with Urochloa covered on stage $\mathrm{V}_{4}$; MBLA: Maize intercropped with Urochloa broadcasted in $\mathrm{V}_{4}$; and $\mathrm{MS}$ : Control; FW: forward wheel slippage; RW: rear wheel slippage; NS: without significance; C.V.: coefficient of variation (\%). 
For the values of displacement speed there was no significant effect between treatments, result justified by the use of the same gear of work and engine rotation. Concerning the values of wheels slippage, it was found that the FW had higher levels of slippage on treatment where the forage was planted at the time of covering fertilizing $\left(\mathrm{V}_{4}\right)$ of the maize, but being statistically equal to the other treatments, only different to the control, which showed lower values.

These results can be explained by the large amount of straw produced by MBC compared to single maize, the behavior of slippage of FW is related to the amount of straw produced in the system (Table 1), where areas with higher amount of dry mass promoted lower adherence of front wheels. Another possible explanation for these results is the dynamic distribution of the weight of the tractor ( $40 \% \mathrm{FW}$ e $60 \% \mathrm{RW})$, which is determined according to the static load on the axis, height of the drawbar, the distance between the axis and the bar maximum strength. This configuration associated with the type of tire can change the advance of the front wheels, supporting the increase of slippage.

But the observed values are above the values suggested by ASABE (2006) which recommends, to obtain maximum traction efficiency, slippage of 8 to $10 \%$ in not mobilized soils, and 11 to $13 \%$ in mobilized soils. The slippage values are within acceptable limits only in the treatment with smaller amount of straw, i.e, the control. According to CEPIK et al. (2010), slippage increases as the amount of residues on the ground increases, effect that can be attributed to deficient contact of the tire with the ground and the straw being composed by fragments not anchored, capable of easy removal by the tire, agreeing in some parts with the results of this research, because in the areas with more mass of residues there was more wheel slippage.

The rear wheel slippage showed no significant difference in any of the evaluated treatments, which can be ascribed to the movement of the straw by the frontal wheels, removing the straw from the central area and allowing more tire contact with the ground, improving adherence and the coefficient traction, and the dynamic weight distribution described previously.

The average traction strength and average power bar had lower values in treatments $\mathrm{C}$ and MBL when compared to MBC. These results suggest that in areas with higher amounts of straw (Table 2), the energy demand of the seeder-tractor is greater. Opposite results were found by CEPIK et al. (2010), that working with doses of residues 0-6 $\mathrm{Mg} \mathrm{ha}^{-1}$, do not showed significant difference in strength required on the stems at different doses in operation with five planting rows, in which case it can be said that there was no influence of the amount of residues on the power demand by the furrower. According to SILVEIRA et al. (2011), working with no tillage system of maize crop, because of the speed of the displacement, the average strength achieved was ranging from $2.42 \mathrm{kN}$ to $2.61 \mathrm{kN}$, values below those found in this study, however superior than the range of force required per line according to ASAE (1996), which are $1.1 \mathrm{kN}$ to $2.0 \mathrm{kN}$.

CONTE et al. (2007) evaluated in area of crop-livestock integration, traction effort demanded by furrowers stems in operation of no tillage system of soybeans in areas with different pasture intensities and concluded that the higher demands of traction occurred in the treatments more pastured likely due to increased soil compaction in areas with smaller amounts of straw. However, in this research the SMRP values are considered low, which confirms the higher energy demand in areas with high ground cover. KAMIMURA et al. (2009) working with seeder-fertilizer with fertilizer furrower performance at two depths $(0.06 \mathrm{~m}$ and $0.12 \mathrm{~m})$, observed that the traction strength was not affected by doses of plant residues $\left(0-6 \mathrm{Mg} \mathrm{ha}^{-1}\right)$.

These results show the importance of the straw on the surface, because regardless of the purpose of crop-livestock integration, whether for production of straw to maintain the annual supply required by the NTS or animal pasture, even requiring greater energy demand of the tractor- seeder, the benefits of straw on the surface can provide the direct increase in grain yield of crops and even keep the operational cost. 


\section{CONCLUSIONS}

The increase in the amount of dry mass on the soil provided by the Urochloas increases the front wheel slippages, strength and average power at the drawbar.

The Urochloa ruzizienses provided greater amount of straw on the soil surface.

The requirement for greater strength and power in the drawbar, as well as the lower adherence of the wheels in the soil, according to the increasing amount straw, may not interfere with the smallest capacity or greater operational cost.

\section{ACKNOWLEDMENTS}

São Paulo Research Foundation (FAPESP) for the concession of the doctorate fellowship to the first author.

\section{REFERENCES}

ANDEROTTI, M.; ARALD M.; GUIMARÃES, V.F.; JUNIOR, E.F.; BUZETTI, S. Produtividade do milho safrinha e modificações químicas de um latossolo em sintema plantio direto em função de espécie de cobertura após calagem superficial. Acta Scientiarum Agronomy, Maringá, v.30, n.1, p.109-115, 2008.

ASAE. AMERICAN SOCIETY OF AGRICULTURAL ENGINEERS. Terminology for soilengaging components for conservation tillage planters, drilss and seedrs. In: . ASAE Standards 1996: standards engineering practices data. St. Joseph, 1996. p.309-314.

ASABE. AMERICAN SOCIETY OF AGRICULTURAL AND BIOLOGICAL ENGINEERS. ASAE D497.5: Agricultural machinery management data. In: . ASAE Standards 2006. St. Joseph, 2006. p.391-398.

CEPIK, C.T.C.; TREIN, C.R.; LEVIEN, R.; CONTE, O. Força de tração e mobilização do solo por hastes sulcadoras de semadoras-adubadoras. Revista Brasileira Engenharia Agrícola e Ambiental, Campina Grande, v.14, n.5, p.561-566, 2010.

CHIODEROLI, C.A.; MELLO, L.M.M.; GRIGOLLI, P.J.; SILVA, J.O.R.; CESARIN, A.L. Consorciação de braquiárias com milho outonal em plantio direto sob pivô central. Engenharia Agrícola, Jaboticabal, v.30, n.6, p.1101-1109, 2010.

CONTE, O.; LEVIEN, R.; TREIN, C.R.; CEPIK, C.T.C.; DEBIASI, H. Demanda de tração em haste sulcadora na integração lavoura-pecuária com diferentes pressões de pastejo e sua relação com o estado decompactação do solo. Engenharia Agrícola, Jaboticabal, v.27, n.1, p.220-228, 2007.

CUNHA, E.Q.; BALBINO, L.C.; STONE, L.F.; LEANDRO, W.M.; OLIVEIRA, G.C. Influência de rotações de culturas nas propriedades físico-hídricas de um Latossolo Vermelho em plantio direto. Engenharia Agrícola, Jaboticabal, v.27, n.3, p.675-682, 2007.

EMBRAPA. EMPRESA BRASILEIRA DE PESQUISA AGROPECUÁRIA. Sistema brasileiro de classificação dos solos. 2.ed. Rio de Janeiro: CNPS, 2006. 306 p.

FREITAS, F.C.L.; FERREIRA, F.A.; FERREIRA, L.R. Cultivo consorciado de milho para silagem com Brachiaria brizantha no sistema de plantio convencional. Planta Daninha, Viçosa, v.23, n.4, p.635-644, 2005.

JAKELAITIS A., SILVA A.F., SILVA A.A., FERREIRA L.R., FREITAS F.C.L., VIANA R.G. Influência de herbicidas e de sistemas de semeadura de Brachiaria brizantha consorciada com milho. Planta Daninha, Viçosa, v.23, n.1, p.59-67, 2005.

JAKELAITIS, A.; SILVA, A.A.; SILVA, A.F.; SILVA, L.L.; FERREIRA, L.R.; VIVIAN, R. Efeitos de herbicidas no controle de plantas daninhas, crescimento e produção de milho e 
Brachiaria brizantha em consórcio. Pesquisa Agropecuária Tropical, Goiânia, v.36, n.1, p.53-60, 2006.

KAMIMURA, K. M.; LEVIEN, R.; TREIN, C.R.; DEBIASI, H.; CONTE, O. Parâmetros solomáquina em função de doses de resíduos vegetais e profundidades de deposição de adubo em semeadura direta. Engenharia Agrícola, Jaboticabal, v.29, n.3, p.431-439, 2009.

MACHADO, L.A.Z.; ASSIS, P.G.G. Produção de palha e forragem por espécies anuais e perenes em sucessão à soja. Pesquisa Agropecuária Brasileira, Brasília, v.45, n.4, p.415-422, 2010.

NUNES, U.R.; JÚNIOR, V.C.A.; SILVA, E.B.; SANTOS, N.F.; COSTA, H.A.O.; FERREIRA, C.A. Produção de palhada de plantas de cobertura e rendimento do feijão em plantio direto. Pesquisa Agropecuária Brasileira, Brasília, v.41, n.6, p.943-948, 2006.

SALVADOR, N.; MION, R.L.; BENEZ, S.H. Consumo de combustível em diferentes sistemas de preparo periódico realizados antes e depois da operação de subsolagem. Ciência e Agrotecnologia, Lavras, v.33, n.3, p.870-874, 2009.

SANTOS, G.G.; SILVEIRA, P.M.; MARCHÃO, R.L.; BECQUER, T.; BALBINO, L.C. Macrofauna edáfica associada a plantas de cobertura em plantio direto em um latossolo vermelho do Cerrado. Pesquisa Agropecuária Brasileira, Brasília, v.43, n.1, p.115-122, 2008.

SILVEIRA, J.C.M.; FERNADES, H.C.; MODOLO, A.J.; SILVA, S.L.; TROGELLO, E. Profundidade de sulco, área de solo mobilizada e força de tração de uma semeadora-adubadora em razão da velocidade de deslocamento. Revista Ceres, Viçosa, v.58, n.3, p.293-298, 2011.

TIMOSSI, P.C.; DURIGAN, J.C.; LEITE, G.J. Formação de palhada por braquiárias para adoção do sistema plantio direto. Bragantia, Campinas, v.66, n.4, p.617-622, 2007. 